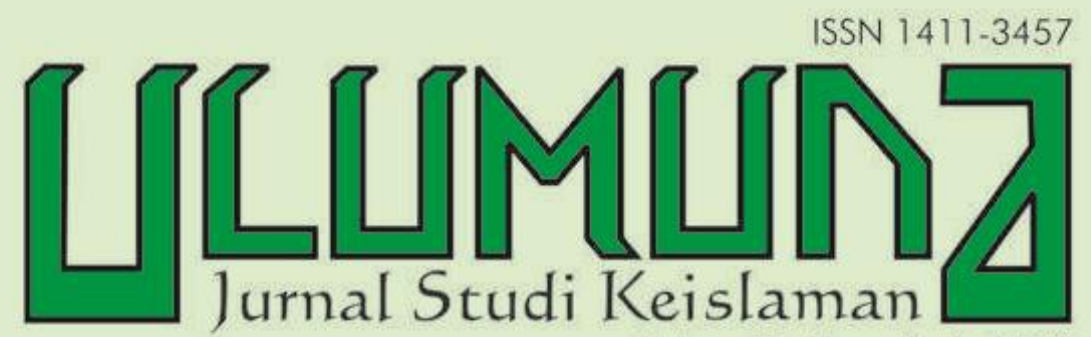

Volume $17 \cdot$ Nomor $1 \cdot$ Juni 2013

TERAKREDITASI B: SK Dirjen Dikti Kemdikbud Nomor: 56/DIKTI/Kep/2012, Tanggal 24 Juli 2012

MENCERNA AKAR FILSAFAT DALAM ISLAM Ismail Fahmi Arrauf PERKEMBANGAN PARADIGMA EPISTEMOLOGI DALAM FILSAFAT ISLAM Fathul Mufid EPISTEMOLOGI ISLAM: KEDUDUKAN WAHYU SEBAGAI SUMBER ILMU Anwar Muiahidin DARI ISLAMISASI ILMU MENUJU PENGILMUAN ISLAM: MELAWAN HEGEMONI EPISTEMOLOGI BARAT Ismail Toib dan Mukhlis INDUKTIVISME SEBAGAI BASIS PENGEMBANGAN ILMU PENGETAHUAN DALAM ISLAM Masdar Hilmy

PERTAUTAN ONTOLOGI FILSAFAT DAN TASAWUF: PERSPEKTIF TENTANG RELASI TUHAN, MANUSIA, DAN ALAM Hadarah Rajab PERTAUTAN EPISTEMOLOGI FILSAFAT DAN TASAWUF: TELAAH SISTEM PEMIKIRAN ABDUL HALIM MAHMUD Lalu Muchsin Effendi ETIKA DALAM FILSAFAT ISLAN:

PEMIKIRAN FILOSOF MUSLIM TENTANG KEBAHAGIAAN Mustain PEngembangan Sumber Daya MANusia DALAM PERSPEKTIF EPESTIMOLOGI FILSAFAT ISLAM Asep Kumiawan 


\section{DAFTAR ISI}

\section{Pedoman Transliterasi}

1-18 • Ismail Fahmi Arrauf,

"Mencerna Akar Filsafat dalam Islam"

19-40 • Fathul Mufid,

"Perkembangan Paradigma Epistemologi

dalam Filsafat Islam"

41-64 • Anwar Mujahidin

"Epistemologi Islam:

Kedudukan Wahyu Sebagai Sumber Ilmu"

65-96 • Ismail Toib dan Mukhlis

"Dari Islamisasi Ilmu Menuju Pengilmuan Islam:

Melawan Hegemoni Epistemologi Barat"

97-126 • Masdar Hilmy

"Induktivisme Sebagai Basis Pengembangan

Ilmu Pengetahuan dalam Islam"

127-152 • Hadarah Rajab

"Pertautan Ontologi Filsafat dan Tasawuf:

Telaah Relasi Tuhan, Manusia, dan Alam"

153-190 • Lalu Muchsin Effendi

"Pertautan Epistemologi Filsafat dan Tasawuf:

Telaah Sistem Pemikiran Abdul Halim Mahmud"

191-212• Mustain

"Etika dan Ajaran Moral Filsafat Islam:

Pemikiran Para Filosof Muslim tentang Kebahagiaan"

\section{3-230 • Asep Kurniawan}

Pengembangan Sumber Daya Manusia

dalam Perspektif Epestimologi Filsafat Islam

\section{APENDIKS}




\section{PEDOMAN TRANSLITERASI}

\begin{tabular}{|c|c|c|c|c|c|c|}
\hline 1 & $=$ & $\mathbf{a}$ & $\dot{\varepsilon}$ & $\dot{\varepsilon}$ & $=$ & $\mathrm{g}$ \\
\hline ب & $=$ & $\mathbf{b}$ & & ف & $=$ & $\mathbf{f}$ \\
\hline$ت$ & $=$ & $t$ & & ق & $=$ & $q$ \\
\hline$\dot{H}$ & $=$ & th & & ك5 & $=$ & $\mathbf{k}$ \\
\hline ج & $=$ & $\mathfrak{j}$ & & j & $=$ & 1 \\
\hline$\tau$ & $=$ & ḥ & & b & $=$ & $\mathbf{m}$ \\
\hline$\dot{\tau}$ & $=$ & $\mathbf{k h}$ & & ن & $=$ & $\mathbf{n}$ \\
\hline د & $=$ & d & & و & $=$ & $\mathbf{w}$ \\
\hline$\dot{j}$ & $=$ & dh & $\circ$ & ○ & $=$ & $\mathbf{h}$ \\
\hline$\jmath$ & $=$ & $\mathbf{r}$ & & $\varepsilon$ & $=$ & , \\
\hline j & $=$ & $\mathbf{z}$ & & ي & $=$ & $\mathbf{y}$ \\
\hline س & $=$ & $\mathrm{s}$ & & & & \\
\hline 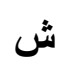 & $=$ & sh & \multicolumn{4}{|c|}{ Untuk Madd dan Diftong } \\
\hline ص - ص & $=$ & ș & i & $=$ & \multicolumn{2}{|c|}{$\bar{a}$ (a panjang) } \\
\hline ض & $=$ & d & إي اي & $=$ & \multicolumn{2}{|c|}{$\overline{1}$ (i panjang) } \\
\hline$b$ & $=$ & $\mathrm{t}$ & أو - & $=$ & \multicolumn{2}{|c|}{$\overline{\mathrm{u}}$ (u panjang) } \\
\hline ظ & $=$ & $\mathrm{z}$ & او - او & $=$ & \multicolumn{2}{|c|}{ aw } \\
\hline$\varepsilon$ & $=$ & 6 & أي & $=$ & \multicolumn{2}{|l|}{ ay } \\
\hline
\end{tabular}

Contoh penulisan dengan transliterasi:

اعوذ بالله من الشيطان الرجيم (a'üdhu bi al-Lāh min al-shaytān al-rajim);

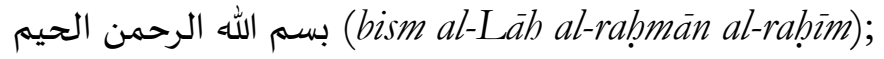

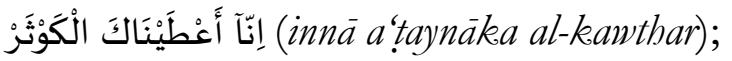

(fasalli lirabbika wanhar);

صباح الخير (șabāh al-khayr). 


\title{
PENGEMBANGAN SUMBER DAYA MANUSIA DALAM PERSPEKTIF EPISTEMOLOGI FILSAFAT ISLAM
}

\author{
Asep Kurniawan \\ (IAIN Syekh Nurjati Cirebon \\ Email: asepqurniawan@yahoo.com)
}

Abstract: Human beings are the only creature whose capability of knowledge enabling them to develop. However, this could be hampered by the wrong epistemology understanding based on a religion they believe. This research aims to encourage buman thought to be dynamically progressive without jeopardizing values of Qur'an. This is carried out through placing the Islamic epistemology on the autonomy of ration and empirical experiences and conducting dialectical process between them and Al-Qur'an. Conclusions derived are that human knowledge can develop dynamically and progressively in line with the spirit of the Qur'an. It automatically has an impact on the development of holistic buman resources. In this context, Islamic epistemology then is the main drive for the development of human resources.

Abstrak: Manusia adalah satu-satu makhluk yang mempunyai potensi untuk mengembangkan diri melalui pengetabuan yang dimilikinya. Namun, hal ini bisa dihambat oleh kesalahan pemahaman pada tingkatan epistemologi. Penelitian ini bermaksud mendorong pemikiran manusia berkembang secara dinamis progresif tanpa kehilangan semangat Qur'ani yang pada akbirnya berdampak kepada perkembangan baik sumber daya manusia yang holistik sebagai hamba yang berpikir dan berdzikir. Metode epistemologi Islam harus diletakkan pada otonomi akal dan pengalaman empiris dalam naungan al-Qur'an yang bersifat dialektika terhadap keduanya. Kesimpulan yang bisa diambil ialah babwa epistemologi Islam merupakan daya gerak bagi perkembangan sumber daya manusia.

Keywords: epistemologi, Islam, sumber daya manusia, pengetabuan, akal, empiri, al-Qur'an 
DEWASA ini, manusia senantiasa mengembangkan potensi yang ada pada dirinya, ia ingin menemukan sesuatu yang bermanfaat bagi orang lain, yang akhirnya menghantarkan kepada penemuan suatu kajian yang dinamakan dengan filsafat ilmu atau sering juga disebut dengan epistemologi. Manusia mampu mengembangkan pengetahuan dari keanekaragaman penciptaan alam semesta ini, karena memang hanya manusia yang mempunyai potensi lebih jika dibandingkan dengan makhluk yang lain. Dia adalah khalifah pemakmur bumi. Manusia adalah satu-satunya makhluk yang mengembangkan pengetahuan secara sungguh-sungguh. Dia memikirkan hal-hal baru, karena dia hidup bukan sekedar untuk kelangsungan hidup, namun lebih dari itu. Manusia mengembangkan kebudayaan; manusia memberi makna kepada kehidupannya; manusia memanusiakan diri dalam hidupnya.

Pengembangan sumber daya manusia berkaitan erat dengan kuantitas dan kualitas pengetahuan yang dimiliki. Keadaan ini menjadi sangat penting karena dari pengetahuanlah manusia mempunyai dasar untuk bertindak, dan dari pengetahuanlah manusia bisa meningkatkan kualitas hidupnya.

Pengembangan sumber daya manusia terkadang terhambat oleh pemikiran epistemologi tertentu yang sering dikaitkan dengan ajaran agama. Sehingga agama yang sejatinya adalah ajaran-ajaran yang universal dan melingkupi seluruh aspek kehidupan manusia harus tereduksi oleh epistemologi yang tidak bisa menangkap "ruh" hakekat epistemologi islami itu sendiri. Ketika menghubungkan epistemologi dengan agama Islam, muncullah sederet pertanyaan yang perlu dijawab, seperti apakah epistemologi Islam atau epistemologi islami? Apa karena ada penempelan ayat-ayat Qur'an dalam diskursus pemikiran filosofis maka dengan mudah dikatakan sebagai epistemologi Islam? Atau juga karena buah pemikiran tersebut keluar dari para filosof muslim yang dikenal di dunia Islam, sebut saja alKindi maka serta merta dikatakan epistemologi Islam?

Pertanyaan-pertanyaan tersebut menjadi renungan. Selama ini pemahaman epistemologi Islam sering cenderung kepada kajian tokoh-tokoh filsafat Islam dengan sederet nama seperti Ibnu Sina, al-Kindi, al-Farabi, Ibnu Rusydi dan lain-lain. Tidak 
salah memang, karena dari merekalah filsafat Islam terutama epistemologinya dapat berkembang. Namun jika hanya ini yang dijadikan patokan tentu akan mereduksi hakekat epistemologi filsafat Islam itu sendiri, karena belum tentu pemikiran mereka sejalan dengan hakekat epistemologi Islam itu sendiri. Oleh karena itu, perlu dirumuskan prinsip-prinsip dasar epistemologi Islam, agar dunia pemikiran Islam terus berkembang sesuai dengan perubahan zaman.

\section{Memahami Hakekat Epistemologi Filsafat Islam}

Epistemologi adalah cabang filsafat yang secara khusus membahas hakekat ilmu. ${ }^{1}$ Bidang ini mempelajari dasar-dasar filsafat, asumsi dan implikasi dari ilmu, yang termasuk di dalamnya antara lain ilmu alam dan ilmu sosial. Di sini, filsafat ilmu sangat berkaitan erat dengan epistemologi dan ontologi. Epistemologi berusaha untuk dapat menjelaskan masalahmasalah seperti: apa dan bagaimana suatu konsep dan pernyataan dapat disebut sebagai ilmiah, bagaimana konsep tersebut dilahirkan, bagaimana ilmu dapat menjelaskan, memperkirakan serta memanfaatkan alam melalui teknologi; cara menentukan validitas dari sebuah informasi; formulasi dan penggunaan metode ilmiah; macam-macam penalaran yang dapat digunakan untuk mendapatkan kesimpulan; serta implikasi metode dan model ilmiah terhadap masyarakat dan terhadap ilmu pengetahuan itu sendiri.

Hakekat dari epistemologi Islam adalah pada akal, pengalaman empiris, dan al-Qur'an. Epistemologi Islam tidak mungkin dapat berjalan tanpa ketiganya secara dialektikal. Pengembangan sumber daya manusia yang menjadikan diskursus ini pun akan kehilangan artinya, sehingga tindakan yang dilakukan tidak bersifat holistik. Akal dan pengalaman empiris menjadikan kegiatan epistemologi maju ke arah pemikiran kritis dan radikal sebagai ciri dari filsafat itu sendiri, sementara itu alQur'an memayungi kegiatan akal dan pengalaman empiris menjadi teduh dengan ciri keislaman. Artinya akal bekerja

1J. L. McKechnie (ed.), Webster's New Twentieth Century Dictionary (New York: Simon and Schuster, 1979), 614; Dani Vardiansyah, Filsafat Ilmu Komunikasi: Suatu Pengantar (Jakarta: Indeks, 2008), 20. 
dengan semangat Qur'ani dan bermoralkan garis-garis yang jelas dari al-Qur'an. Dialektika akal dan pengalaman empiris dengan al-Qur'an memposisikan akal dan pengalaman empiris untuk bekerja memecahkan masalah sedangkan al-Qur'an memberikan rambu-rambu moralitas terhadapnya.

Dalam dunia filsafat Islam, setidaknya ada tiga corak epistemologi, yaitu pengetahuan rasional (al-Farabi, Ibnu Sina, Ibnu Bajjah, Ibnu Tufail, Ibnu Rusydi, dan lain-lain), pengetahuan inderawi (cuma terbatas kepada klasifikasi sumber perolehan ilmu pengetahuan, tetapi belum ada filosof muslim yang mengembangkan epistemologi ini seperti Empirisme di Barat), dan epistemologi kashf (Sufism) yang diperoleh melalui ilham. Kenyataan yang ada selama ini terlihat bahwa epistemologi rasional dan kashf yang sangat mendominasi filsafat Islam. Akibatnya epistemologi filsafat Islam kurang dapat berkembang dengan baik. Sebagai contoh pemikiran al-Ghazali yang memisahkan secara jelas antara ilmu agama dengan ilmuilmu sekuler secara perlahan melemahkan semangat keilmuan yang kritis di dunia Islam. Fenomena ini dapat terlihat nyata manakala kita membaca sejarah Islam terutama di abad pertengahan, kita dapat memahami bahwa filsafat dan ilmu-ilmu sekuler sebagai buah pemikiran kreatif manusia mendapat penolakan yang besar. ${ }^{2}$

Dalam pemikiran Sufism, kehidupan di atas dunia dan apa yang terjadi di atas dunia adalah sesuatu yang fana atau bukan yang sebenarnya. Dunia ini hanyalah penampakan dan bukan realitas yang sesungguhnya. Bagaikan penampakan yang ada di cermin yang memiliki bentuk tetapi bukan realitas sesungguhnya. ${ }^{3}$ Kehidupan ini hanya sekedar persinggahan semata dalam perjalanan kehidupan panjang yang sebenarnya, yaitu akherat. Kehidupan di dunia merupakan permainan dan senda gurau. Senangnya merupakan kesenangan yang menipu, sedihnya merupakan kesengsaraan sementara. Itulah dinamakan

2Amin Abdullah, "Aspek Epistimologis Filsafat Islam”, Filsafat Islam, ed. Irma Fatimah (Yogyakarta, LESFI, 1992), 35-6.

3 John Bousfield, "Islamic Phylasophy in South East Asia", Islam in South East Asia, ed. M.B. Hooker (Leiden: E.J. Brill, 1983), 96. 
kehidupan di alam fana. Sungguh berbeda dengan kehidupan sejati dan abadi di akhirat nanti.

Dalam rentang sejarah pemikiran Islam, corak Sufism yang berbau metafisika sangat begitu terasa. Corak pemikiran ini sering bersinggungan dengan pemikiran metafisika Platonis atau Neo-Platonis yang berpandangan manusia sudah sempurna dengan ide bawaan di luar dunia empiris. ${ }^{4}$ Nampak ada keterputusan yang jelas antara dunia idea metafisika yang dipandang kekal dan tetap dengan dunia real kehidupan empiris manusia. Walaupun begitu golongan ini berpendapat dunia idea tersebut adalah yang esensi dalam upaya manusia mengembangkan dirinya dalam memperoleh pengetahuan. Dalam perwujudan corak metafisika ini, manusia diharuskan serba merenung, mengingat-ingat idea yang telah dilihatnya sebelum di alam dunia. Namun bagaimana menghubungkan dunia idea yang non empiris tersebut ke dua empiris manusia ketika pengalaman indra harus dinafikkan? Bukankah manusia lahir tidak sempurna (tahu apa-apa) tapi dianggap tahu apa-apa? Lalu, jika memang ia idea bawaan, bagaimana memunculkan kesempurnaan manusia tersebut dari ketidaksempurnaan kalau hanya merenung? Disinilah terdapat keterputusan makna dengan realitas.

Dalam sejarah Islam terutama abad pertengahan setelah runtuhnya Dinasti Abbasiyah, pemikiran epistemologi dunia Islam sangat lekat dalam dominasi metafisika kalam di satu sisi dan dominasi spekulatif Sufism di sisi yang lain. Inilah yang mengakibatkan stagnasi epistemologi Islam dan akhirnya menjadikan kurangnya daya gerak terhadap pengembangan sumber daya manusia, sehingga pada fase ini umat Islam mengalami kemunduran peradaban.

Sebenarnya dalam pembahasan epistemologi sudah jelas ditegaskan bahwa sifat dari ilmu pengetahuan adalah fana atau relatif. Artinya kebenaran ilmu pengetahuan berubah-ubah sesuai sifat pemikiran manusia yang terbatas. Semua ilmu pengetahuan adalah konstruski ciptaan individual manusia. Oleh karena itu sifatnya relatif dalam arti tergantung pada cara pandang si pencipta ilmu pengetahuan, sifat dan aspek yang

${ }^{4}$ Abdullah, “Aspek..., 37. 
diamati, serta kondisi-kondisi lain yang mengikat seperti waktu, tempat, dan lingkungan sekitarnya. Terbatas, semua ilmu pengetahuan adalah "abstraksi" tentang sesuatu hal, yang berarti suatu teori bersifat terbatas.

Kebenaran yang ditemukan oleh manusia pada suatu saat mungkin dangkal atau diubah dengan kebenaran yang baru. Pengetahuan yang tidak cocok lagi dengan hasil-hasil pengamatan baru, diganti dengan pengetahuan lebih memenuhi keperluan para ilmuwan, teori geosentris Ptolomeus dalam tata surya pada abad pertengahan di ganti oleh teori heliosentris Galileo Galilei. Demikian juga dalam Kimia Phlogiston Theory ${ }^{5}$ yang memberikan keterangan yang berbeda dengan teori oksidasi jatuh dan ditinggalkan oleh orang yang berkecimpung di dalam ilmu Kimia. Untuk sinar dalam Fisika, teori partikel dan teori gelombang masih dapat berjalan bersama. Teori generation spontance untuk makhluk hidup sekarang ini dalam Biologi diganti oleh More vivo ex ovo, omne ovo ex vivo. ${ }^{6}$ Teori Darwin tentang asal mula manusia dari kera $^{7}$ yang dibantah teori sel modern

${ }^{5}$ Menurut teori Phlogiston bahwa semua materi yang dapat terbakar mengandung zat ringan yang disebut "Phlogiston" dan sewaktu materi terbakar, phlogiston akan lepas ke udara \& sisa pembakaran tidak mengandung phlogiston lagi. Jadi, menurut teori ini, massa zat akan lebih ringan. Tetapi, pembakaran pada calx logam (oksida logam), massa hasil pembakaran justru lebih besar. Namun, beberapa pendukung teori phlogiston berargumen bahwa phlogiston dapat bermassa negatif. Lihat, Peter J. Bowler, Making Modern Science: A Historical Survey (Chicago: University of Chicago Press, 2005), 134; William Hodson Brock, The Norton history of chemistry, (New York: W. W. Norton, 1993), 264.

${ }^{6}$ Dari percobaan Louis Pasteur, Fransisco Redi, Antoni Van Leuwenhoek, teori abiogenesis yang sempat bertahan sampai beberapa tahun akhirnya tumbang. Kemudian timbul slogan berbunyi Omne Vivum Ex Ovo, Omne Ovum Ex Vivo, yang artinya makhluk hidup berasal dari telur dan telur berasal dari kehidupan sebelumnya (Omne Vivum ex Ovo = makhluk hidup berasal dari telur, Omne Ovum ex Vivo = telur berasal dari makhluk hidup). Walaupun demikian belum berarti sudah bisa menjawab tentang asal-usul kehidupan. Karena masih banyak ahli yang berusaha mengungkap kebenaran teori biogenesis seperti Harold Urey, Stanlley Multer, dan Oparin. James Strick, "Introduction", Evolution \& The Spontaneous Generation (London: Continuum International Publishing Group, 2001), xi-xxiv.

${ }^{7}$ C.B. Stringer, "Evolution of Early Humans", The Cambridge Encyclopedia of Human Evolution, ed. Steve Jones, Robert Martin \& David Pilbeam 
bahwasannya asal mula manusia itu dari tanah. Atom berdasarkan teori Dalton, ${ }^{8}$ atom adalah partikel yang paling kecil tetapi kenyataannya ada yang lebih kecil dari atom yaitu neutron atau proton, maka gugurlah teori Dalton.

Walaupun pengetahuan manusia bersifat relatif dan "jatuh bangun" mampu mendorong dinamika pengetahuanpengetahuan dan penemuan-penemuan baru. Sehingga, manusia mampu menciptakan pemikiran-pemikiran yang lebih berkembang dari sebelumnya. Justru disinilah kekuatannya. Manusia mampu mengembangkan kompetensi dirinya dengan penciptaan pengetahuan bagi kepentingan kehidupan. Artinya pengembangan sumber daya bisa bergerak progresif dengan epistemologi yang dinamis.

\section{Kriteria Kebenaran Epistemologi Islam}

Berpikir merupakan suatu kegiatan untuk menemukan pengetahuan yang benar. Apa yang disebut benar bagi seseorang belum tentu benar bagi orang lain. Karena itu, kegiatan berpikir adalah usaha untuk menghasilkan pengetahuan yang benar itu atau kriteria kebenaran. Pada setiap jenis pengetahuan tidak sama kriteria kebenarannya karena sifat dan watak pengetahuan itu berbeda. Pengetahuan alam metafisika tentunya tidak sama dengan pengetahuan tentang alam fisik. Alam fisik pun memiliki perbedaan ukuran kebenaran bagi setiap jenis dari bidang pengetahuan.

(Cambridge: Cambridge University Press. 1994), 242; H.M. McHenry, "Human Evolution", Evolution: The First Four Billion Years, ed. Michael Ruse \& Joseph Travis (Cambridge, Massachusetts: The Belknap Press of Harvard University Press, 2009), 265.

8John Dalton (1766-1844) ialah seorang guru SMU di Manchester, Inggris. Ia terkenal karena teorinya yang membangkitkan kembali istilah "atom". Dalam buku karangannya yang berjudul New System of Chemical Pbilosophy ia berhasil merumuskan hal tentang atom sekitar tahun 1803. Ia menyatakan bahwa materi terdiri atas atom yang tidak dapat dibagi lagi. Tiap-tiap unsur terdiri atas atom-atom dengan sifat dan massa identik, dan senyawa terbentuk jika atom dari berbagai unsur bergabung dalam komposisi yang tetap. Temuannya didasarkan pada sebuah eksperimen. Henry E. Roscoe dan Arthur Harden, A New View of the Origin of Dalton's Atomic Theory (London: Macmillan. 2007), 248. 
Problem kebenaran inilah yang memacu tumbuh dan berkembangnya epistemologi. Telaah epistemologi terhadap kebenaran membawa orang kepada sesuatu kesimpulan bahwa perlu dibedakan adanya tiga jenis kebenaran, yaitu kebenaran epistemologi, kebenaran ontologis, dan kebenaran semantis. ${ }^{9}$ Kebenaran epistemologis adalah kebenaran yang berhubungan dengan pengetahuan manusia, kebenaran dalam arti ontologis adalah kebenaran sebagai sifat dasar yang melekat pada hakikat segala sesuatu yang ada atau diadakan. Kebenaran dalam arti semantis adalah kebenaran yang terdapat serta melekat dalam tutur kata dan bahasa.

Namun, dalam pembahasan ini hanya dibahas kebenaran epistemologis saja karena kebenaran yang lainnya secara inheren akan masuk dalam kategori kebenaran epistemologis. Dalam kajian epistemologi Islam terdapat beberapa kriteria kebenaran, yaitu: Pertama, Kriteria Korespondensi. Kebenaran dapat didefinisikan sebagai kesetiaan pada realitas objektif, yaitu suatu pernyataan yang sesuai dengan fakta atau sesuatu yang selaras dengan situasi. Kebenaran adalah persesuaian antara pernyataan mengenai fakta dengan fakta aktual: atau antara putusan dengan situasi seputar yang diberi interpretasi. ${ }^{10}$ Kedua, Kriteria Konsistensi. Menurut kriteria ini kebenaran tidak dibentuk atas hubungan antara putusan dengan sesuatu yang lain yaitu fakta atau realitas, tetapi atas hubungan antara putusan-putusan yang baik dengan putusan lainnya yang telah diakui kebenarannya terlebih dahulu. Arti lain, suatu proposisi itu cenderung untuk benar jika proposisi itu saling berhubungan dengan proposisiproposisi lain yang benar, atau jika arti yang dikandung oleh proposisi yang saling berhubungan dengan pengalaman kita. ${ }^{11}$ Jadi sesuatu itu benar, hubungan itu saling berhubungan dengan

${ }^{9}$ Aholiab Watholy, Tanggung Jawab Pengetahuan (Yogyakarta: Kanisius, 2001), 157.

${ }^{10}$ Richard L. Kirkham, Theories of Truth: A Critical Introduction (Cambridge: MA MIT Press, 1992), 4; Amsal Bakhtiar, Filsafat Ilmu (Jakarta: Raja Grafindo Persada, 2006), 112-3; Jujun S. Sumantri, Filsafat Ilmu (Jakarta: Pustaka Sinar Harapan, 2003), 57; Hardono Hadi, Epistemologi: Filsafat Pengetahuan (Yogyakarta: Kanisius, 1997), 148.

${ }^{11}$ Watholy, Tanggung..., 159; W.V. Quine dan Ullian, J.S., The Web of Belief (New York: Random House, 1978), 87. 
kebenaran sebelumnya. Ketiga, Kriteria Pragmatis. Menurut teori pragmatisme, suatu kebenaran dan suatu pernyataan diukur dengan kriteria apakah pernyataan tersebut bersifat fungsional dalam kehidupan manusia. Teori, hipotesa atau ide adalah benar apabila ia membawa kepada akibat yang memuaskan, apabila ia mempunyai nilai praktis. Kebenaran terbukti oleh kegunaannya, oleh hasilnya, dan oleh akibat-akibat praktisnya. ${ }^{12}$

Dalam kenyataannya kini, kriteria kebenaran cenderung menekankan satu atau lebih dari tiga pendekatan; (1) yang benar adalah yang memuaskan keinginan kita, (2) yang benar adalah yang dapat dibuktikan dengan eksperimen, (3) yang benar adalah yang membantu dalam perjuangan hidup biologis. Oleh karena kriteria kebenaran (koresponden, konsistensi, dan pragmatisme) itu lebih bersifat saling menyempurnakan daripada saling bertentangan, maka teori tersebut dapat digabungkan dalam suatu definisi tentang kebenaran. Kebenaran adalah persesuaian yang setia dari pertimbangan dan ide manusia kepada fakta pengalaman atau kepada alam seperti adanya. Akan tetapi karena manusia dengan situasi yang sebenarnya, maka dapat diujlah pertimbangan tersebut dengan konsistensinya dengan pertimbangan-pertimbangan lain yang manusia menganggap sah dan benar, atau manusia menguji dengan faedahnya dan akibatakibatnya yang praktis.

\section{Sumber Daya Manusia dalam Konteks Epistemologi Islam}

Al-Qur'an tidak menggolongkan manusia ke dalam kelompok binatang (animal) selama manusia mempergunakan akalnya dan karunia Tuhan lainnya. Namun, kalau manusia tidak mempergunakan akal dan berbagai potensi pemberian Tuhan yang sangat tinggi nilainya yakni pemikiran (rasio), kalbu, jiwa, raga, serta panca indra secara baik dan benar, ia akan menurunkan derajatnya sendiri menjadi hewan seperti dalam firman Allah Swt. dalam Qs. al-A'rāf (7): 179 yang artinya, "...Mereka punya hati, tetapi tidak dipergunakan untuk memahami ayat-ayat Allah, punya mata tetapi tidak dipergunakan untuk melihat tanda-tanda kekuasaan Allah, punya

${ }^{12 B a k h t i a r, ~ F i l s a f a t . . ., ~} 119$. 
telinga tetapi tidak dipergunakan untuk mendengar ayat-ayat Allah. Mereka (manusia) yang seperti itu sama martabatnya dengan hewan bahkan lebih rendah dari binatang."

Di dalam al-Qur'an manusia disebut antara lain dengan bani $\bar{A}$ dam, ${ }^{13}$ bashar, ${ }^{14}$ al-Insān ${ }^{15}$ dan al-Nās. ${ }^{16}$ Penyebutan nama manusia dalam al-Qur'an dengan berbagai istilah itu untuk menunjukkan dari berbagai aspek kehidupan manusia, di antaranya:

1. Dari aspek historis penciptaan manusia disebut dengan bani Ādam. Sebagaimana Firman Allah yang artinya: "Hai anak Adam, pakailah pakaianmu yang indah disetiap memasuki masjid, makan dan minumlah dan janganlah berlebih-lebihan. Sesungguhnya Allah tidak menyukai orang-orang yang berlebih-lebihan.” (Qs. al-A'raf [7]: 31).

2. Dari aspek biologis manusia disebut dengan bashar yang mencerminkan sifat-sifat fisik-kimia-biologisnya. Manusia perlu makan, minum, menikah, dan lain-lain. Sebagaimana firman Allah yang artinya: "Dan berkatalah pemuka-pemuka yang kafir diantara kaumnya dan yang mendustakan akan menemui hari akhirat (kelak) dan yang telah (Kami mewahkan mereka dalam kehidupan di dunia). Orang ini tidak lain hanyalah manusia (bashar) seperti kamu, dia makan dari apa yang kamu makan dan meminum dari apa yang kamu minum." (Qs. alMu'minūn [23]: 33).

3. Dari aspek kecerdasan manusia disebut dengan insān yakni makhluk terbaik yang diberi akal sehingga mampu menyerap ilmu pengetahuan. Dan manusia dibebani tanggung jawab, pengemban amanat dan khalifah Allah di bumi. Sebagaimana Firman Allah yang artinya: "Dia menciptakan manusia (insān). Mengajarnya pandai bicara." (Qs. al-Rahmān [55]: 3-4).

4. Dari aspek sosiologis manusia disebut al-nās yang menunjukkan sifatnya yang berkelompok sesama jenisnya.

${ }^{13}$ Qs. al-Isra' (17): 70.

${ }^{14}$ Qs. al-Kahfi (18): 110.

${ }^{15}$ Qs. al-Insān (76): 1.

${ }^{16}$ Qs. al-Nās (114): 1. 
Sebagaimana Firman Allah yang artinya: "Wahai manusia, sesungguhnya kami menciptakan kamu dari seorang lakilaki dan seorang perempuan dan menjadikan kamu berbangsa-bangsa dan bersuku-suku supaya kamu saling mengenal..." (Qs. al-Hujurat [49]: 13).

5. Dari aspek posisinya disebut 'abd (hamba) yang menunjukkan kedudukannya sebagai hamba Allah yang harus tunduk dan patuh kepada-Nya. Sebagaimana Firman Allah yang artinya: "Maka apakah mereka tidak melihat langit dan bumi yang ada di hadapan dan di belakang mereka? jika Kami menghendaki niscaya Kami benamkan mereka di bumi atau Kami jatuhkan mereka gumpalan dari langit. Sesungguhnya pada yang demikian itu benar-benar terdapat tanda (kekuasaan Tuhan) bagi setiap hamba yang kembali kepada-Nya." (Qs. al-Saba' [34]: 9).

Dengan demikian dapat dipahami bahwa manusia adalah satu-satunya makhluk Allah yang diberi kesempurnaan baik fisik, rohani, dan akalnya agar mampu menjadi khalifah di bumi ini. Diberikan akal dan indra agar mampu berpikir, memahami alam semesta, mempelajarinya, mencari manfaatnya bagi diri dan makhluk lain. Tubuh manusia yang mempunyai daya fisik atau jasmani, yang terdiri dari indra penglihatan, penciuman, perasa, perabaan, pendengaran, daya gerak. Semuanya berhubungan dengan unsur-unsur materi. Manusia adalah makhluk somatopsiko-sosial-spiritual, yang terdiri dari fisik, jiwa, spiritual, dan makhluk yang harus berinteraksi secara sosial dengan orang lain yang keempatnya saling berinteraksi karena unsur-unsur tersebut saling berkait, dan saling mempengaruhi sejak saat pembuahan sampai akhir hayatnya. Semua permasalahan yang timbul harus dicari keterkaitannya dengan melihat keempat unsur tersebut, agar pemecahannya masalah manusia lebih optimal.

Di samping itu Allah menciptakan manusia dilengkapi pula dengan kelemahannya. Kelemahan manusia harus dikendalikan dengan pengembangan diri melalui pengetahuan yang diperolehnya, sedangkan kelebihan manusia lebih ditingkatkan dengan pengembangan diri pula agar berkembang lebih optimal. 
Pengembangan diri ini secara hakikat adalah untuk memanusiakan manusia.

\section{Peranan Epistemologi Filsafat Islam dalam Pengembangan Sumber Daya Manusia}

Manusia mempunyai potensi untuk mengembangkan pengetahuannya dengan cepat dan mantap karena manusia mampu berpikir menurut suatu alur kerangka berpikir tertentu. Manusia mampu mengkomunikasikan informasi dan jalan pikiran yang melatarbelakangi informasi tersebut. Oleh karena itu, manusia sering diistilahkan sebagai makhluk yang mampu berpikir (bomo sapien).

Perkembangan ilmu pengetahuan manusia akan menentukan perkembangan kehidupannya secara individu juga masyarakat bahkan negara atau dunia. Dengan kata lain, dengan ilmu pengetahuan manusia dapat berkembang dengan pesat dan maju. Pengembangan ilmu pengetahuan dan sumber daya manusia ternyata merupakan kekuatan yang sangat dominan dalam menentukan perkembangan kualitas kehidupan. Manusia mampu mengembangkan pengetahuannya dengan cepat dan mantap karena manusia mampu berpikir menurut suatu alur kerangka berpikir tertentu. Manusia mampu mengomunikasikan informasi dan jalan pikiran yang melatarbelakangi informasi tersebut.

Al-Qur'an adalah Kitab Suci yang memberikan banyak isyarat tentang epistemologi bagi pengembangan sumber daya manusia, walaupun kita tidak bisa mengatakan bahwa al-Qur'an adalah kitab ilmu pengetahuan, karena sifat kebenaran al-Qur'an adalah pasti benarnya, sementara ilmu pengetahuan adalah bersifat relatif. Firman Allah dalam Qs. al-Nahl (16): 78, "Dan Allah mengeluarkan kamu dari perut ibumu dalam keadaan tidak mengetahui sesuatu apa pun, dan Dia memberi kamu pendengaran, penglihatan dan hati, agar kamu bersyukur". AlQur'an dengan begitu jelas mengatakan bahwa manusia adalah makhluk yang tidak tahu apa-apa ketika dilahirkan, namun Allah memberikan bekal manusia untuk mengembangkan dirinya dengan modal indra yang bisa menangkap fenomena empiri pengetahuan, berupa pendengaran, penglihatan, dan hati. Jika 
dihubungkan dengan epistemologi idea Plato yang telah dijelaskan di muka bahwa manusia sudah membawa apa-apa, tentu sangat bertolak belakang.

Ketika manusia belum mampu menginternalisasikan potensinya secara nyata, pendengaran menjadi sarana paling tepat untuk mengembangkan sumber daya manusia. Hal ini tidak saja karena pendengaran adalah instrumen awal yang potensial untuk pengembangan sumber daya manusia, tetapi juga karena pendengaran adalah sumber daya manusia yang erat kaitannya dengan daya ingat dan mencerna yang di dalamnya dapat dilihat dari kesanggupan seseorang dalam mengungkapkan kembali apa yang ada dengan menjelaskan, menguraikan, dan menggambarkan apa yang telah diterima melalui penggunaan daya pendengaran. Kedua daya ini mengandung unsur kehatihatian yang erat kaitannya dengan konsentrasi dan imajinasi kreatif. Tanpa sifat ini tidak mungkin manusia untuk menampung sebanyak-banyak informasi dan menuangkannya kembali sesuai dengan apa yang ia dengar dengan menghindarkan diri dari kesalahan-kesalahan yang akan mengganggu nilai kebenarannya.

Al-Qur'an juga menganjurkan untuk melakukan perjalanan dan menjadikan pengalaman sebagai pelajaran yang harus dimanfaatkan. Karena itu, dalam pandangan al-Qur'an wujud yang yang diinformasikan oleh panca indra - selama dalam wilayah kerjanya - dapat diandalkan dan bahwa apa yang dijangkaunya adalah satu kenyataan. Ini selama indra itu tidak mengalami gangguan dari dalam dan luar dirinya. Selanjutnya alQur'an memerintahkan manusia untuk menggunakan nalarnya dalam menimbang ide yang masuk ke dalam benaknya. Banyak ayat yang berbicara tentang hal ini dan dengan berbagai redaksi seperti ta'qilün, tatafakkarün dan lain-lain. Ini membuktikan bahwa akal pun mampu meraih pengetahuan dan kebenaran, juga selama ia digunakan dalam wilayah kerjanya.

Pengetahuan harus dicari dengan indra yang telah Allah anugerahkan kepada manusia. Walaupun pengetahuan indra diragukan kebenarannya karena indra bersifat terbatas, tapi hal ini bisa dilakukan dengan cara abstraksi, yaitu proses panjang dan ketelitian pengamatan manusia terhadap suatu obyek 
tertentu, lalu akal akan mampu mengabstraksikan ideanya. Dari proses ini menghasilkan hukum-hukum pengetahuan yang universal.

Tingkat relativitas pengetahuan empiri manusia menjadi sesuatu yang sinergi dengan perkembangan pengetahuan yang terus bergerak maju untuk terus menguak tentang alam semesta ini yang begitu luas. Sebagaimana Allah berfirman dalam Qs. alKahf (18): 109: "Jika lautan (yang ada di dunia ini) adalah tinta, dan pepohanan adalah pena, tidak akan sanggup untuk menulis ilmu Allah, walaupun ditambahkan lagi jumlah seluruh lautan yang sama." Makna dari ayat tersebut seyogiannya ditarik kepada makna rasa ingin tahu manusia yang harus terus dipacu untuk menguak sebanyak-banyak rahasia alam semesta yang merupakan mahakarya Allah swt. Ayat ini menantang manusia, semakin dikaji dan diamati alam semesta maka akan semakin terbuka hal-hal yang perlu terus ditelaah. Bukan sebaliknya ditekankan kepada makna kelemahan manusia akan betapa kecilnya ilmu manusia di tengah-tengah ilmu Allah yang tiada batas. Walaupun tidak salah memang, namun jika makna ini yang terus mendominasi pemikiran manusia maka akan menjadikan matinya giroh untuk mengembangkan diri sebagai makhluk yang dinamis.

Kegiatan manusia untuk mengembangkan dirinya dan menemukan pengetahuan yang benar adalah sesuatu yang harus dilakukan karena manusia selalu berpikir. Namun setiap manusia berbeda cara berpikirnya untuk menemukan suatu kebenaran yang hakiki. Dapat dikatakan bahwa setiap jalan pikiran mempunyai kriteria kebenaran, yang merupakan landasan bagi proses penemuan kebenaran tersebut, penalaran merupakan suatu penemuan kebenaran dimana tiap-tiap jenis penaralaran mempunyai kriteria kebenarannya masing-masing.

Al-Qur'an memberikan isyarat yang jelas akan perintahperintah untuk meneliti alam semesta untuk kepentingan manusia. Firman Allah dalam perumpamaan yang begitu indah seperti yang disebutkan di atas memberikan makna akan proses dalam epistemologi. Proses, karena manusia tidak serta merta peroleh pengetahuan kalau tidak ada upaya untuk mencarinya. Bukankah sudah sangat jelas bahwa manusia asalnya tidak tahu 
apa-apa menjadi tahu apa-apa karena Allah memberikan bekal indra untuk pengalaman empiris pengetahuan manusia? Juga, bukankah betapa banyak ayat al-Qur'an yang menyuruh manusia untuk menggunakan indranya? Afalā yanzurün (apakah kamu tidak melihat), 'alam tara (tidakkah kamu melihat), un₹uru (lihatlah), falyanzur (maka hendaklah memperhatikan), afala táqilūn (apakah kamu tidak memikirkan), dan lain-lain. Ada 854 kali al-Qur'an menyebutkan ayat-ayat yang memberi isyarat ilmu pengetahuan dengan indra sebagai alat untuk memperolehnya. Maka, bagaimana jadinya jika hanya karena dasar pemahaman empiri manusia yang terbatas, kemudian manusia tidak boleh mengandalkannya untuk mengembangkan diri dengan pencarian ilmu pengetahuan? Tentu hal ini sulit bisa dipahami dan bahkan bertentangan dengan perintah al-Qur'an tersebut.

Ambil contoh, proses pencarian Tuhan yang bersifat metafisik sekalipun dilakukan oleh Nabi Ibrahim as. menggunakan pengalaman empiris inderawi. Beliau memperhatikan fenomena masyarakat di sekitarnya dan bahkan ayahnya sendiri yang menyembah berhala, adalah sesuatu yang bertentangan dengan akal sehatnya. Kemudian beliau memperhatikan secara bertahap benda-benda langit, yaitu bulan, bintang, dan matahari sebagai Tuhan. Pada akhirnya sampai pada kesimpulan bahwa Tuhan bukanlah sesuatu yang terbatas. ${ }^{17}$ Artinya al-Qur'an memberikan penekanan kepada penggunaan pengalaman empiris untuk menangkap hukum-hukum sesuatu seperti yang tergambar dalam pengalaman Nabi Ibrahim as.

Proses pencarian pengetahuan dalam rangka berdzikir kepada-Nya digambarkan dalam al-Qur'an sebagai orang-orang yang berdzikir kepada Allah sambil berdiri, duduk atau dalam keadaan berbaring, dan mereka memikirkan tentang penciptaan langit dan bumi sambil berkata: "Ya Tuhan kami, tidaklah Engkau menciptakan semua ini sia-sia; Maha Suci Engkau, lindungilah kami dari azab neraka". ${ }^{18}$ Dari ayat ini secara jeli dapat dilihat bahwa mengingat Allah (dhikir) tidak semata hanya ingat secara pasif, tetapi juga ada upaya dalam keadaan apapun untuk menelaah penciptaan Alam (kauniyab) oleh Allah swt yang

${ }^{17}$ Qs. al-An'ām (6): 74-9.

${ }^{18}$ Qs. Ali 'Imron (3): 191. 
menghantarkan kepada pengakuan akan kuasa Allah dan kesempurnaan ciptaan-Nya yang tiada batas.

Dalam dimensi yang lain ayat tersebut mengandung makna proses manusia secara epistemologi untuk mengembangkan dirinya menyingkap alam untuk kepentingan manusia itu sendiri. Makna dbikir di sini bisa sejalan dalam konteks yang lebih luas. Bukankah orang yang berhasil menemukan suatu hukum dan karya pengetahuan serta banyak bermanfaat kepada sesama manusia disebut juga implementasi dhikir? Penulis rasa apa yang dipesankan al-Qur'an adalah makna dhikir seperti ini. Lagi, bukankah akhlak yang dikehendaki Islam adalah memberikan kemanfaatan sebanyak-banyaknya terhadap manusia? Bahkan dalam hadis Rasulullah ilmu yang bermanfaat adalah investasi besar yang tiada terputus walaupun orang yang menciptkannya telah meninggal dunia. ${ }^{19}$ Penulis berandai-andai, jika seorang Thomas Alva Edison adalah orang Islam maka buah karya pengetahuannya yaitu bola lampu akan menjadi investasi pahala baginya yang tiada terputus, karena telah memberi kemanfaatan kepada berjuta dan bahkan bermilyar manusia dari masa ke masa. Dengan demikian, mengapa pengertian dhikir harus senantiasa bermakna tradisional? Maha Karya Agung ayat-ayat kauniyah yang ada di sekitar manusia nampaknya akan sayang jika manusia melewatkan begitu saja untuk tidak dikaji.

Al-Qur'an senantiasa menjelaskan bahwa pengetahuan manusia sangat bervariasi dan bermacam-macam, serta tidak akan pernah mencapai titik perhentian. Teori yang diyakini kebenarannya pada suatu masa, boleh jadi akan menjadi usang di suatu masa tertentu seiring ditemukannya temuan-temuan baru oleh manusia. Inilah makna proses perkembangan epistemologi manusia.

Dampak dari proses perkembangan epistemologis manusia adalah perkembangan kualitas sumber daya manusia itu sendiri. Sehingga tidak berlebihan jika semakin tinggi kualitas epistemologi manusia atau bisa juga cara bepikir seseorang maka otomatis pengembangan yang ada pada diri seseorang semakin tinggi pula. Dari sini dapat dipahami peranan ilmu atau epistemologi terhadap pengembangan sumber daya manusia

${ }^{19}$ Imam Muslim, Sabih Muslim (Riyadh, Dār Ibnu Hisham, 2011), 1631. 
sangat erat kaitannya atau saling ketergantungan. Karena sumber daya manusia yang tinggi tergantung dari pemikiran-pemikiran atau ilmu yang dimiliki manusia.

Manusia mengembangkan pengetahuan, dari pengetahuannya itu muncul daya pikir bagaimana mengatasi kebutuhan dan kelangsungan hidup. Jadi potensi yang dimiliki seseorang menjadi penentu kehidupan pada dirinya. Sehingga peranan epistemologi terhadap pengembangan sumber daya manusia saling berkaitan satu sama lain.

\section{Catatan Akhir}

Epistemologi Islam jika dimaknai dan diimplementasikan dengan benar akan menjadi daya gerak bagi kemajuan pengembangan sumber daya manusia melalui penggalian ilmu pengetahuan yang dinamis dan sustainable, karena memberikan spirit bagi perkembangan dan kemajuan ilmu dan sekaligus nilainilai moral yang terkandungnya, sebab hakikat epistemologi Islam terletak pada integrasi penggunaan akal, empiris, dan alQur'an. Akal dan indra bekerja menangkap sesuatu obyek untuk menghasilkan hukum-hukumnya sementara al-Qur'an memberi rambu-rambu moralitas atas kerja akal dan indra.

Perkembangan ilmu pengetahuan manusia akan menentukan perkembangan kehidupannya, artinya manusia dengan ilmu pengetahuan yang masih sederhana tingkat perkembangannya tidak akan secepat dan sebaik dengan manusia yang tingkat perkembangannya ilmu pengetahuan dan sumber daya manusia yang lebih maju. Pengembangan ilmu pengetahuan dan sumber daya manusia merupakan kekuatan yang sangat dominan dalam menentukan perkembangan peradaban manusia. Ilmu pengetahuan merupakan salah satu hasil dari usaha manusia untuk memperadab dirinya, ilmu dapat dianggap sebagai suatu sistem yang menghasilkan kebenaran. Seperti itu pula sistemsistem yang lainnya mempunyai komponen-komponen yang berhubungan satu sama lainnya. Wa al-Lāh a lam bi al-sawāh. 


\section{Daftar Pustaka}

Abdullah, Amin. 1992. “Aspek Epistemologis Filsafat Islam”, Filsafat Islam, ed. Irma Fatimah. Yogyakarta, LESFI.

Bakhtiar, Amsal. 2006. Filsafat Ilmu. Jakarta: Raja Grafindo Persada.

Bousfield, John. 1983. "Islamic Philosophy in South East Asia", Islam in South East Asia, ed. M.B. Hooker. Leiden: E.J. Brill.

Bowler, Peter J. 2005. Making Modern Science: A Historical Survey.

Chicago: University of Chicago Press.

Brock, William Hodson. 1993. The Norton history of chemistry. New York: W. W. Norton.

Hadi, Hardono. 1997. Epistemologi: Filsafat Pengetahuan. Yogyakarta: Kanisius.

Kirkham, Richard L. 1992. Theories of Truth: A Critical Introduction. Cambridge: MA MIT Press.

McHenry, H.M. 2009. "Human Evolution", Evolution: The First Four Billion Years, ed. Michael Ruse \& Joseph Travis. Cambridge, Massachusetts: The Belknap Press of Harvard University Press.

McKechnie, J. L. (ed.). 1979. Webster's New Twentieth Century Dictionary. New York: Simon and Schuster.

Quine, W.V. dan Ullian, J.S., 1978. The Web of Belief. New York: Random House.

Roscoe, Henry E dan Arthur Harden, 2007. A New View of the Origin of Dalton's Atomic Theory. London: Macmillan.

Strick, James 2001. "Introduction", Evolution \& The Spontaneous Generation. London: Continuum International Publishing Group.

Stringer, C.B. 1994. "Evolution of Early Humans", The Cambridge Encyclopedia of Human Evolution, ed. Steve Jones, Robert Martin \& David Pilbeam. Cambridge: Cambridge University Press.

Sumantri, Jujun S. 2003. Filsafat Ilmu. Jakarta: Pustaka Sinar Harapan.

Vardiansyah, Dani. 2008. Filsafat Ilmu Komunikasi: Suatu Pengantar. Jakarta: Indeks.

Watholy, Aholiab. 2001. Tanggung Jawab Pengetahuan. Yogyakarta: Kanisius. 